\section{Film i stadens tjänst: Göteborg 1938-2015}

\section{Erik Florin Persson}

Institutionen för kulturvetenskaper

Akademisk avhandling för avläggande av filosofie doktorsexamen i filmvetenskap vid Göteborgs universitet, som med tillstånd av humanistiska fakultetens dekanus kommer att offentligen försvaras fredagen 4 juni $2021 \mathrm{kl}$. 13.00 i sal J303, Humanisten, Renströmsgatan 6, Göteborg.

Opponent: Professor Pelle Snickars, Umeå universitet

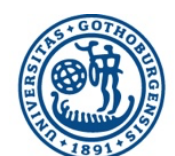

\section{GÖTEBORGS UNIVERSITET}

\section{Abstract}

PhD dissertation in Film Studies at University of Gothenburg, Sweden, 2021

Title: Film i stadens tjänst: Göteborg 1938-2015

English title: Film in service of the city: Gothenburg $1938-2015$

Author: Erik Florin Persson

Language: Swedish, with an English summary

Department: Department of Cultural Sciences, University of Gothenburg, Box 200, SE-405 30 Göteborg

Published by: Mediehistoriskt arkiv

ISBN: 978-91-985801-8-1 (print), 978-91-985801-9-8 (pdf)

Fulltext online: http://mediehistorisktarkiv.se/bocker/film-i-stadens-tjanst-goteborg-1938-2015/

The aim of this dissertation is to map and analyze the production of municipal city films in Gothenburg between 1938 and 2015 in relation to economic and political changes of the city. Covering a total of fourteen larger film projects as well as several shorter films, the focus of the study lies both on the commission, distribution, and screening of the studied films and on the manner in which the city of Gothenburg and its inhabitants are represented. In this, the study contributes both to the growing research field of so-called useful cinema within film studies and to research on municipal propaganda, information, and marketing. Earlier research on the latter has primarily focused on the period after the 1970s. In contrast, this thesis gives a longer historical perspective on these activities, studying them both during the welfare-state period and throughout the shift to a market-oriented mode of urban governance of the late 2000s.

The results of the study show that moving images have been a crucial part of the municipal information, propaganda, and marketing activities throughout the study period. Many of the older films were produced with a multitude of aims and target groups, such as tourists, business industries and the city's inhabitants. Their screening contexts include cinema's program of shorts, classrooms and tourists' organizations. Many of them also had a wide international distribution. By mapping both the pre-production process and the way the films move through different screening contexts, the study shows the ambiguity that characterizes many useful films and the fleeting boundaries between concepts such as propaganda, information, and marketing, at least until the 1980s. From 1990s onwards the films have more specific target groups and stand more clearly out as marketing material for attracting tourists and businesses.

The study also demonstrates that the way the image of the city and its inhabitants has been constructed throughout the studied period can be read in relation to broader economic and political changes in the city. In this, different aspects of the city and its history have been used in a strategic way to construct contemporary arguments about the it.

Key words: useful cinema, sponsored film, non-fiction film, non-theatrical film, city branding, municipal city film, local film history 